\title{
EPSPS Gene Amplification is Present in the Majority of Glyphosate-Resistant Illinois Waterhemp (Amaranthus tuberculatus) Populations
}

\author{
Laura A. Chatham, Chenxi Wu, Chance W. Riggins, Aaron G. Hager, Bryan G. Young, Gordon K. \\ Roskamp, and Patrick J. Tranel*
}

\begin{abstract}
With the frequency of glyphosate-resistant waterhemp increasing throughout the Midwest, the identification of resistant populations has become important for managing this species. However, high-throughput screening for glyphosate resistance in the greenhouse is tedious and inefficient. Research was conducted to document the occurrence of glyphosate-resistant waterhemp throughout the state of Illinois, and to determine whether a molecular assay for 5-enolypyruvyl-shikimate-3phosphate synthase (EPSPS) gene amplification can be used as an alternative means to detect resistant populations. Populations throughout the state of Illinois were collected in 2010 and screened for glyphosate resistance using a whole-plant assay in a greenhouse, and survivors were examined for EPSPS gene amplification. Of 80 populations investigated, 22 were glyphosate resistant based on the greenhouse screen, and gene amplification was identified in $20(91 \%)$ of the resistant populations. Although there are multiple mechanisms for glyphosate resistance in waterhemp, a molecular test for EPSPS gene amplification provides a rapid alternative for identification of glyphosate resistance in most populations.
\end{abstract}

Nomenclature: Glyphosate; common waterhemp, Amaranthus tuberculatus (Moq.) Sauer var. rudis (Sauer).

Key words: EPSPS gene amplification, glyphosate-resistant waterhemp, Pro106Ser mutation, resistance detection, resistance monitoring.

\begin{abstract}
Con el incremento en la frecuencia de Amaranthus tuberculatus resistente a glyphosate a lo largo del Medio oeste, la identificación de poblaciones resistentes se ha hecho importante para el manejo de esta especie. Sin embargo, la evaluación rápida y de cantidades grandes de muestras para detectar resistencia a glyphosate en el invernadero es tediosa e ineficiente. Se realizó una investigación para documentar la frecuencia de $A$. tuberculatus resistente a glyphosate a lo largo del estado de Illinois, y determinar si una prueba molecular evaluando la amplificación del gen de 5-enolpyruvyl-shikimate-3-phosphate synthase (EPSPS) puede ser usado como una alternativa para detectar poblaciones resistentes. Las poblaciones a lo largo del estado de Illinois fueron colectadas en 2010 y evaluadas por resistencia a glyphosate usando una prueba con plantas enteras en un invernadero, y las plantas sobrevivientes fueron examinadas para detectar la amplificación del gen EPSPS. De las 80 poblaciones investigadas, 22 fueron resistentes a glyphosate con base en la evaluación en el invernadero, y la amplificación del gen se identificó en $20(91 \%)$ de las poblaciones resistentes. Aunque existen múltiples mecanismos de resistencia a glyphosate en $A$. tuberculatus, una prueba molecular de amplificación del gen EPSPS brinda una alternativa rápida para la identificación de resistencia a glyphosate en la mayoría de las poblaciones.
\end{abstract}

\footnotetext{
DOI: $10.1614 /$ WT-D-14-00064.1

* First, second, third, fourth, and seventh authors: Graduate Student, Graduate Student, Research Assistant Professor, Associate Professor, and Professor (ORCID: 0000-00030666-4564), Department of Crop Sciences, University of Illinois, Urbana, IL 61801; fifth author: Professor, Department of Plant, Soil, and Agricultural Systems, Southern Illinois University, Carbondale, IL 62901; sixth author: Professor, Department of Agriculture, Western Illinois University, Macomb, IL 61455. Current address of fifth author: Department of Botany and Plant Pathology, Purdue University, West Lafayette, IN 47907. Corresponding author's E-mail: tranel@illinois.edu
}

Glyphosate-resistant (GR) crops were first commercialized in 1996 and, within a decade, 96\% of all soybean [Glycine $\max (\mathrm{L}$.) Merr.] grown in the United States were GR, as well as $61 \%$ of all corn (Zea mays L.) (Dill et al. 2008). The intensive use of glyphosate due to the widespread adoption of GR crops increased selection for GR weeds. In 2000, horseweed [Conyza canadensis (L.) Cronq.] in GR soybean was the first weed to evolve resistance to glyphosate in a GR crop (VanGessel 2001). To date, 28 weed species worldwide have evolved resistance to glyphosate (Heap 2014). 
The first documented GR waterhemp population was identified in a Missouri field with a history of continuous GR soybean and multiple glyphosate applications per year (Legleiter and Bradley 2008). GR waterhemp has now spread throughout Missouri (Rosenbaum and Bradley 2013; Schultz et al. 2014), Illinois (Riggins et al. 2012), and much of the central United States (Heap 2014). An investigation of the spread of glyphosate resistance from a single resistant population in Illinois suggests that independent selection events and long distance dispersal may both be responsible for GR waterhemp evolution and spread (Liu et al. 2010).

Glyphosate targets 5-enolypyruvyl-shikimate-3phosphate synthase (EPSPS), an enzyme present in the chloroplasts of plants and in some bacteria. By blocking EPSPS activity, glyphosate ultimately prevents the synthesis of aromatic amino acids and all downstream products of the shikimic acid pathway. Currently identified mechanisms of weed resistance to glyphosate include reduced translocation (Lorraine-Colwill et al. 2003) most likely due to vacuolar sequestration (Ge et al. 2010), EPSPS point mutations (Baerson et al 2002; Wakelin and Preston 2006), and EPSPS gene amplification (Gaines et al. 2010; Salas et al. 2012).

Amplification of the EPSPS gene was first identified as a GR mechanism in Palmer amaranth (Amaranthus palmeri S. Wats.), a weed species closely related to waterhemp (Gaines et al. 2010). While the mechanism of EPSPS gene amplification remains unknown, it is believed to be DNA mediated, as intron sequences are maintained in the amplified copies (Gaines et al. 2013). Preliminary reports indicated that EPSPS gene amplification is present in waterhemp, but the extent to which it contributes to glyphosate resistance was unclear (Bell et al. 2009; Shaner et al. 2011; Tranel et al. 2011). Subsequent reports have confirmed that gene amplification is associated with glyphosate resistance in waterhemp but also that other mechanisms exist (Chatham et al. 2013). In addition to gene amplification, a Pro106Ser point mutation and reduced glyphosate translocation were found to confer resistance in some waterhemp populations (Bell et al. 2013; Nandula et al. 2013).

Identification of resistant populations can help growers make more informed management decisions. However, high-throughput screening for resistance in the greenhouse can be an inefficient use of time and resources. While tests other than greenhouse whole-plant screening have been developed and utilized for glyphosate-resistance detection, these tests have various drawbacks. For example, the resistance in-season quick (RISQ) test using seedlings germinated on herbicide-treated agar and the well-documented shikimate assay both require physiologically active whole plants or tissues (Burgos et al. 2013). In contrast, DNA-based tests can be performed on non-living tissue samples. Tests using quantitative polymerase chain reaction (qPCR) to detect EPSPS gene amplification have been used in the past to screen for glyphosate resistance in samples submitted by growers (Tranel et al. 2011). However, if glyphosate resistance is conferred by another mechanism, a false negative result will occur using this test. Therefore, the primary objective of this study was to determine what proportion of glyphosate-resistant waterhemp populations in Illinois contains EPSPS gene amplification. A secondary objective was to determine the distribution of GR waterhemp in Illinois. Waterhemp populations were obtained from counties throughout Illinois and screened for glyphosate resistance in the greenhouse. Surviving plants were evaluated to determine what percentage of resistant populations had EPSPS gene amplification.

\section{Materials and Methods}

Seed Collection. Seeds were collected from one or more agronomic fields in each of 80 Illinois counties during late summer in 2010 to obtain a wide representation of waterhemp populations in the state. Our objective was to obtain GR populations; therefore, rather than randomly sampling fields, we targeted fields in which GR waterhemp was suspected. Consequently, soybean fields were preferentially sampled over corn fields (since glyphosate is more likely to be the primary or sole herbicide used in the former), and waterhemp plants that likely received a herbicide application were sampled (e.g., plants that were growing in a sprayer skip or that may have emerged after application were avoided).

From each field sampled, inflorescences from multiple female plants (typically five) were collected and pooled. Inflorescences were allowed to dry and seeds were threshed and stored at 4 C. Seeds obtained from a single field were designated as a 
population, and one population per county was arbitrarily selected for further analysis. Prior to resistance screening, a subsample of seeds from each of the selected 80 populations was stratified to break seed dormancy. For stratification, seeds were first sterilized for $10 \mathrm{~min}$ in a $1: 1$ commercial bleach : deionized water solution. The seeds were then washed twice with deionized water, suspended in a $0.1 \%$ agarose solution, and stored at $4 \mathrm{C}$ for at least $6 \mathrm{wk}$ prior to germination.

Resistance Testing. Germination, Planting, and Growth of Waterhemp. Seeds were germinated in standard sterile petri dishes lined with filter paper and moistened with deionized water. Petri dishes were sealed with Parafilm (Pechiney Plastic Packaging, Menasha, WI 54952) to prevent evaporation and placed in a germination chamber (Conviron, 590 Berry St., Winnipeg, Manitoba, Canada R3H 0R9) set to 12-hr days at $35 \mathrm{C}$ and 12-hr nights at $15 \mathrm{C}$. After $48 \mathrm{hr}$, seedlings of uniform size were transplanted into cone-tainers $(3.8 \mathrm{~cm}$ top diam by $21 \mathrm{~cm}$ deep; Stuewe and Sons Inc., 31933 Rolland Dr, Tangen, OR 97389) filled with a $3: 1: 1: 1$ mixture of commercial potting mix (Sunshine Mix \#1 / LC1, Sun Gro Horticulture, 770 Silver Street, Agawam, MA 01001) : soil : peat : sand. Plants were grown in a greenhouse set to 16-hr days with supplemental lighting to maintain a minimum of $800 \mu \mathrm{mol} \mathrm{m}{ }^{-2} \mathrm{sec}^{-1}$. Greenhouse experiments were not performed during the winter months when day length was short; even with supplemental lighting plants often flowered early and glyphosate activity was inconsistent. Temperature in the greenhouse was kept at 28 to $30 \mathrm{C}$ during the day and 24 to 26 $\mathrm{C}$ at night. Plants were fertilized as needed with a solid slow-release fertilizer (Scott's Osmocote Classic 13-13-13, The Scotts Company, 1411 Scottslawn Rd., Marysville, OH 43041).

Herbicide Application and Resistance Evaluation. Fourteen plants of uniform size ( 4 to $5 \mathrm{~cm}$ tall) were chosen from each population and treated with glyphosate (Roundup WeatherMax, Monsanto Company, 800 N. Lindbergh Blvd., St. Louis, MO 63167) at $1260 \mathrm{~g}$ ae ha $\mathrm{ha}^{-1}$. A pool of waterhemp seed collected from multiple Illinois counties in 2003 was used as a glyphosate-sensitive control, and the MO1 population (Legleiter and Bradley 2008) was used as a glyphosate-resistant control. Plants from both negative and positive controls were included in each spray pass. Herbicide application was carried out using a moving-nozzle cabinet spray chamber equipped with a 80015 even flat fan nozzle (TeeJet Technologies, P.O. Box 7900, Wheaton, IL 60187) held approximately 46 $\mathrm{cm}$ above the plant canopy. The spray chamber was calibrated to deliver $187 \mathrm{~L} \mathrm{ha}^{-1}$.

At 14 DAT, individual plants were visually evaluated and rated as sensitive (no green tissue), intermediate (some green tissue but little or no new growth) or resistant (abundant new growth). A population was considered resistant if two or more resistant individuals were present among the 14 individuals, or if one resistant individual and two or more intermediate individuals were present. The experiment was repeated on all populations identified as resistant. During both experimental runs, tissue samples were taken from plants categorized as resistant for molecular investigation of resistance mechanisms. Tissue samples consisted of a single, newly emerging leaf, approximately 1 to $2 \mathrm{~cm}$ long.

Examination of Resistance Mechanisms. Sample Preparation. DNA was extracted using the hexadecyltrimethylammonium bromide (CTAB) method previously described by Doyle and Doyle (1990) and was examined for quality and quantity using a spectrophotomer (NanoDrop 1000 Spectrophotometer, Thermo Fisher Scientific, 81 Wyman St., Waltham, MA 02451). Samples were diluted to 10 ng $\mu^{-1}$ for all downstream applications.

EPSPS Gene Amplification. Copy number of the EPSPS gene relative to a one-copy reference gene was determined by qPCR using methods described previously (Délye et al. 2014; Ma et al. 2013). For populations that had a large number of resistant plants, a subset was arbitrarily selected for analysis of EPSPS gene amplification. Overall, 5 to 17 plants were analyzed for each resistant population.

A threshold relative copy number was chosen based on a distribution of relative EPSPS gene copy numbers from sensitive controls used on each plate of qPCR in this study. These sensitive controls were derived from 12 glyphosate-sensitive populations obtained throughout Illinois. The average copy number for sensitive controls was 0.98 and ranged from 0.60 to 1.87 . The copy numbers from the sensitive controls were reciprocally transformed to normalize the data, and the copy number that was greater than $95 \%$ of the sensitive control values was 
rounded to the nearest tenth and set as the threshold. Samples with a copy number equal to or greater than this threshold, 1.4, were considered to have elevated EPSPS gene copy number.

Alternative Target-Site Resistance. Some resistant plants were further analyzed for the EPSPS Pro106Ser point mutation (Bell et al. 2013; Nandula et al. 2013) using a derived cleaved amplified polymorphic sequences (dCAPS) assay designed according to procedures described by Délye et al. (2014). A fragment containing codon 106 was amplified using the forward primer EPSf1 (5'-ATG TTG GAC GCT CTC AGA ACT CTT GGT-3') originally designed for qPCR (Gaines et al. 2010) and reverse primer eps106wt-R3 (5'-CTC CAG CAA CGG CAA CCG CAA CTG TCE ATG-3'). The reverse primer was engineered to create a NcoI restriction site by substituting a cytosine for an adenine at the fourth nucleotide from the $3^{\prime}$ end of the primer. The resulting PCR product was subjected to a restriction enzyme digest with Nco1 (New England BioLabs Inc., 240 County Road, Ipswich, MA 01938) and then fractionated on a $2 \%$ agarose gel containing $0.5 \mu \mathrm{g} \mathrm{ml} \mathrm{m}^{-1}$ ethidium bromide. Gels were visualized with ultraviolet light and results were compared to samples from known glyphosate-susceptible waterhemp plants.

EPSPS Gene Sequencing. A subset of samples with the Pro106Ser point mutation identified using the dCAPS assay was sequenced to confirm the accuracy of the assay. PCR products from primers EPSF1 and eps106wt-R3 were visualized with gel electrophoreses as described above to confirm the presence of the correct amplicon. The remaining PCR product was purified (E.Z.N.A. Cycle Pure Kit, Omega Bio-Tek, Inc., 400 Pinnacle Way, Suite 450, Norcross, GA 30071) and used in a sequencing reaction (BigDye Terminator v3.1 Cycle Sequencing Kit, Applied Biosystems Inc., 850 Lincoln Centre Drive Foster City, CA 94404) using the EPSF1 primer. The resulting product was analyzed by the W.M. Keck Center for Comparative and Functional Genomics using an AB 3730xl DNA analyzer (Applied Biosystems Inc.). EPSPS gene sequences were aligned to waterhemp sequences from glyphosate-susceptible lines in GenBank (FJ869881 and FJ869880) using MEGA6 (Tamura et al. 2013).

\section{Results and Discussion}

From 80 populations sampled throughout Illinois in 2010, $22(28 \%)$ were identified as glyphosate resistant (Figure 1). All 22 populations were verified as resistant during the second screen. Our observed frequency should not be taken as the probability that any one field in Illinois now contains GR waterhemp because: (1) sampling was non-random and biased towards suspect GR populations; (2) the frequency of resistance varied across the state, with the majority of resistant populations coming from the southern part of the state; and (3) sampling was performed in 2010 and the frequency of GR waterhemp likely has increased.

Because fields were targeted in which GR waterhemp was suspected, we were surprised that such a low percentage of the populations were, in fact, glyphosate resistant. The fact that less than a third of the populations were confirmed as glyphosate resistant suggests that the appearance of waterhemp in fields near the end of the growing season more often than not was due to management practices rather than to glyphosate resistance. Alternatively, the low frequency of resistant populations found in this study may be due in part to the relatively conservative set of criteria used to differentiate between sensitive and resistant populations. These strict criteria were used to reduce the risk of falsely identifying resistant populations, but it may have excluded populations with low frequencies or low magnitudes of resistance. Our results are in contrast to those reported by Riggins et al. (2012), who found that at least two-thirds of waterhemp populations suspected of glyphosate resistance were truly resistant. In their study, however, growers who had site history and management information on which to base their suspicions - submitted the samples. As we found in the present study, identifying GR waterhemp populations without such information is difficult. Rosenbaum and Bradley (2013) showed that signs of waterhemp survival of herbicides, such as stunting or excessive branching resulting from loss of the apical meristem, were strong indicators of glyphosate resistance. We did not use this criterion during our sampling.

The majority of waterhemp populations, $86 \%$, were collected in soybean fields, while only $14 \%$ were collected in corn fields (Figure 1). All populations identified as resistant were collected 


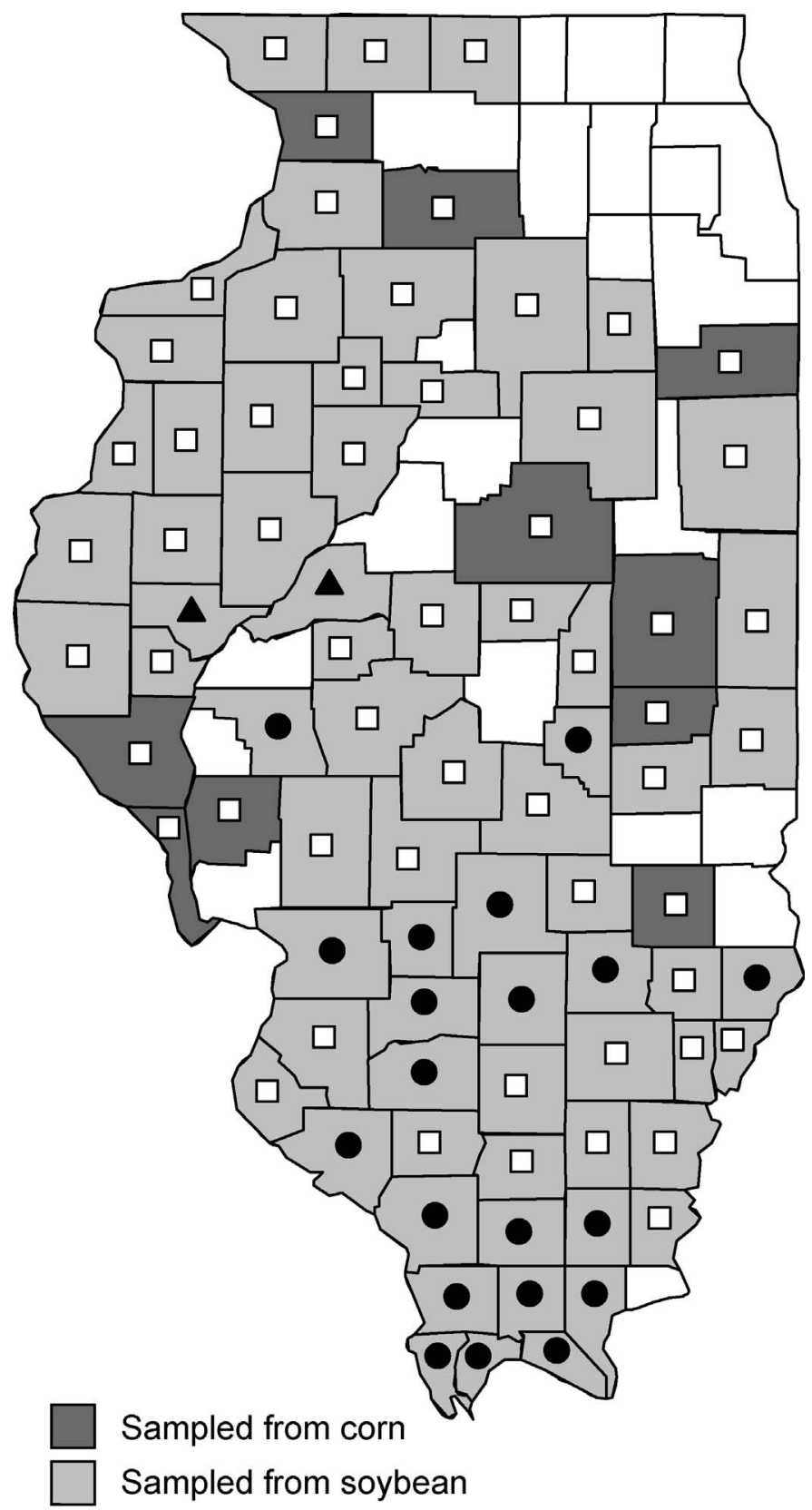

- Resistant with EPSPS gene amplification

A Resistant without EPSPS gene amplification

\section{$\square$ Sensitive}

Figure 1. Map of Illinois counties from which populations were collected for glyphosate-resistance screening. County shading identifies the crop planted in the field from which each analyzed population was collected; results from whole-plant resistance screening and EPSPS gene amplification analysis are indicated by symbols within the counties. from soybean fields. While this may be simply an artifact of the unequal collection of populations from corn and soybean fields, it suggests that waterhemp escapes in soybean fields are more likely to be glyphosate resistant. There are fewer POST herbicide options to control waterhemp in soybean than in corn; therefore, reliance on glyphosate in soybean is likely to be higher than in corn.

Examination of Resistance Mechanisms. Analysis of resistant plants for EPSPS gene amplification revealed that $91 \%$ of GR populations had at least one survivor with gene amplification (Table 1). Only two resistant populations, from Schuyler and Mason counties, did not have plants with elevated EPSPS gene copy number based on the threshold value used. This comprised only $9 \%$ of the resistant populations studied. These results are consistent with previous findings that gene amplification is associated with glyphosate resistance in multiple geographic locations (Chatham et al. 2012, 2013).

Of the resistant populations with EPSPS gene amplification, seven had elevated copy number in every resistant plant sampled. The remaining 13 populations had elevated copy numbers in varying proportions of the total plants sampled. While it is possible that this is due to escapes (i.e., some of the survivors were not resistant), it is likely that some of the populations have an additional mechanism(s) of resistance. Chatham et al. (2012) also found a number of GR waterhemp plants without gene amplification.

The average copy number of the plants with copy number above the threshold in each population was determined to look at the variation in copy number magnitude among populations. With the exception of the populations from Morgan and Bond counties, all populations had an average copy number above 3.0, with the highest average copy number at 8.6 in the Lawrence County population. While these averages are significantly lower than those originally observed in Palmer amaranth (Gaines et al. 2010), they are similar to those observed in kochia [Kochia scoparia (L.) Schrad.] (Wiersma 2012) and in a Palmer amaranth population from New Mexico (MohseniMoghadam et al. 2013). Morgan and Bond populations each had a relatively low proportion of plants with elevated copy number as well as a low average copy number among those that breached the threshold value. It is possible that these populations may not 
Table 1. Summary of populations identified as glyphosate resistant (GR) through greenhouse screening and quantitative polymerase chain reaction (qPCR) screening for 5-enolypyruvyl-shikimate-3-phosphate synthase (EPSPS) gene amplification. Data from two experimental runs were pooled.

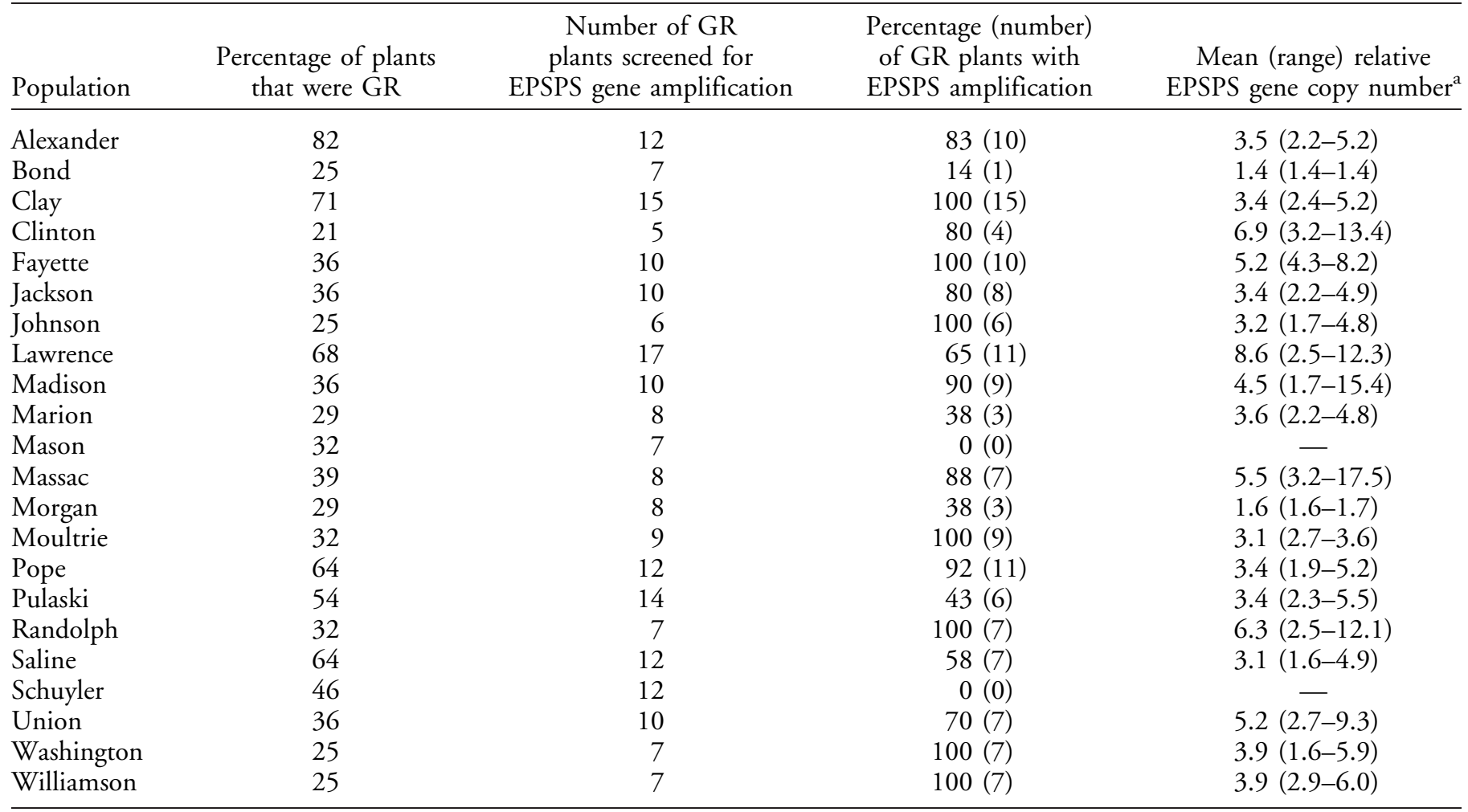

${ }^{a}$ Includes only those plants in which EPSPS gene amplification was greater than or equal to the threshold value of 1.4 .

truly have EPSPS gene amplification; the plants with elevated copy number in these populations may fall within the $5 \%$ of sensitive plants with copy number above the set threshold value. Given the uncertainty of the presence of gene amplification in these two populations, a more conservative estimate of the false negative rate when using gene amplification as a proxy for glyphosate resistance would be $18 \%$.

Further investigation of alternative mechanisms of resistance was carried out using a dCAPS assay designed to detect the Pro106Ser mutation resulting from a cytosine to thymine nucleotide change previously identified in waterhemp (Bell et al. 2013; Nandula et al. 2013). The assay employs the use of a restriction enzyme, $\mathrm{NcoI}$, which cuts an amplified region of EPSPS without the Pro106Ser mutation (i.e., the wild-type), producing a smaller DNA fragment that migrates faster during agarose gel electrophoresis. Samples from the two populations without gene amplification, as well as samples from resistant populations in which gene amplification was not present in all plants, were tested using the assay. The Pro106Ser point mutation was found in the majority of samples from the Schuyler County population (Figure 2). All samples with the mutation were heterozygous, but this is not surprising given that only $43 \%$ of the Schuyler population survived glyphosate treatment. Assuming Hardy-Weinberg proportions (Hartl and Clark 1989), it can be determined that the EPSPS allele with serine at amino acid 106 in the Schuyler County population will be mostly present in heterozygotes, with only about 1 in 17 plants expected to be homozygous for this allele. The Pro106Ser mutation was also found at a low frequency in several other populations (data not shown). In the population from Lawrence County, the mutation was found in several resistant plants without gene amplification. The Pro106Ser mutation also showed up at a low frequency in GR individuals from the Madison, Jackson, and Morgan County populations. A subset of samples from the populations with the Pro106Ser mutation was chosen for sequencing, which confirmed the accuracy of the assay (Figure 2). Although the Pro106Ser mutation does appear to be associated with resistance, questions remain regarding the magnitude of resistance that this mutation confers. 




Figure 2. (A) Results of the dCAPS assay for the identification of the Pro106Ser point mutation in waterhemp showing samples of each possible genotype: homozygous with two proline alleles, heterozygous with one proline and one serine, and homozygous with two serine alleles. (B) Assay results from a subset of Schuyler County population samples, each of which was heterozygous with one proline allele and one serine allele. (C-E) Chromatograms showing the nucleotide sequence of codon 106 in each of the genotypes illustrated in (A): proline/proline (C), proline/serine (D), serine/serine (E).

While Nandula et al. (2013) consistently found the mutation in all GR samples, Bell et al. (2013) observed mortality of some plants with the Pro106Ser mutation at higher glyphosate rates. Further investigation of the interplay between multiple mechanisms of resistance in the populations studied here may be worthwhile. For example, the discovery of amplified EPSPS containing the Pro106Ser point mutation could provide information regarding the evolution of these resistance mechanisms.

The results herein suggest that a third mechanism of glyphosate resistance may be acting in Illinois waterhemp populations. Assuming EPSPS gene amplification is the primary mechanism of resistance in Illinois waterhemp populations, the majority of resistant populations should have elevated EPSPS copy number in all resistant individuals. However, elevated EPSPS copy number was not found in all resistant individuals for the majority of the resistant populations with gene amplification (Table 1). This suggests that the majority of the resistant populations found in Illinois may have multiple mechanisms of glyphosate resistance. Nandula et al. (2013) found nontarget-site resistance in a waterhemp population from Mississippi. Non-target-site-based mechanisms may be able to explain the resistant population that did not have elevated copy number or the Pro106Ser mutation, as well as the large number of populations that had gene amplification present in some, but not all, resistant individuals. Translocation studies in addition to dose responses and genetic inheritance studies would be necessary to identify any alternative glyphosate resistance mechanisms working in these populations.

In summary, this study suggests that EPSPS gene amplification is present in the majority of glyphosate-resistant waterhemp populations from Illinois, but that other mechanisms also exist. However, neither the existence of other mechanisms nor the full accounting of resistance by gene amplification precludes the use of gene amplification as a suitable proxy for glyphosate resistance in waterhemp, as long as a small false negative rate is acceptable. While a more thorough, multi-year survey of glyphosate resistance throughout Illinois is necessary to more accurately describe the distribution and spread of GR waterhemp, the current study provides data to support the use and accuracy of various molecular tools for the identification of GR waterhemp in such studies.

\section{Acknowledgments}

We thank Kevin Bradley from the University of Missouri for providing the MO1 population. The USDA National Institute of Food and Agriculture (Hatch project ILLU-802-923) and the Illinois 
Soybean Association and Soybean Checkoff provided partial funding of this research.

\section{Literature Cited}

Baerson SR, Rodriguez DJ, Tran M, Feng Y, Viest NA, Dill GM (2002) Glyphosate-resistant goosegrass. Identification of a mutation in the target enzyme 5-enolpyruvylshikimate-3phosphate synthase. Plant Physiol 129:1265-1275

Bell MA, Hager AG, Tranel PJ (2013) Multiple resistance to herbicides from four site-of-action groups in waterhemp (Amaranthus tuberculatus). Weed Sci 61:460-468

Bell MS, Tranel PJ, Riggins CW (2009) Glyphosate resistance in waterhemp: inheritance and EPSPS copy number. North Central Weed Sci Soc Proc 64:100

Burgos NR, Tranel PJ, Streibig JC, Davis VM, Shaner D, Norsworthy JK, Ritz C (2013) Review: conformation of resistance to herbicides and evaluation of resistance levels. Weed Sci 61:4-20

Chatham LA, Riggins CW, Martin JR, Kruger GR, Bradley KW, Peterson DE, Jugulam M, Tranel P (2013) A multi-state study of the association between glyphosate resistance and EPSPS gene amplification in waterhemp. North Central Weed Sci Soc Proc 68:127

Chatham LA, Riggins C, Owen MD, Tranel P (2012) Association of EPSPS gene amplification with glyphosate resistance in waterhemp. North Central Weed Sci Soc Proc 67:50

Délye C, Duhoux A, Pernin F, Riggins CW, Tranel PJ (2014) Research methods in weed science: molecular mechanisms of herbicide resistance. Weed Sci 62:In press

Dill GM, Jacob CA, Padgette SR (2008) Glyphosate-resistant crops: adoption, use and future considerations. Pest Manag Sci 64: 326-331

Doyle JJ, Doyle JL (1990) Isolation of plant DNA from fresh tissue. Focus 12:13-15

Gaines TA, Wright AA, Molin WT, Lorentz L, Riggins CW, Tranel PJ, Beffa R, Westra P, Powles SB (2013) Identification of genetic elements associated with EPSPS gene amplification. PloS one 8(6): e65819

Gaines TA, Zhang W, Wang D, Bukun B, Chisholm ST, Shaner DL, Nissen SJ, Patzoldt WL, Tranel PJ, Culpepper AS, Grey TL, Webster TM, Vencill WK, Sammons RD, Jiang J, Preston C, Leach JE, Westra P (2010) Gene amplification confers glyphosate resistance in Amaranthus palmeri. Proc Natl Acad Sci USA 107:1029-1034

Ge X, d'Avignon DA, Ackerman JJH, Sammons RD (2010) Rapid vacuolar sequestration: the horseweed glyphosate resistance mechanism. Pest Manag Sci 66:345-348

Hartl DL, Clark AG, eds (1989) Principles of Population Genetics. 2nd edn. Sunderland, MA: Sinauer Associates, Inc. Pp 31-34

Heap IM (2014) International Survey of Herbicide Resistant Weeds. http://www.weedscience.org. Accessed May 13, 2014

Legleiter TR, Bradley KW (2008) Glyphosate and multiple herbicide resistance in common waterhemp (Amaranthus rudis) populations from Missouri. Weed Sci 56:582-587
Liu J, Tranel PJ, Davis AS (2010) Modeling the spread of glyphosate resistant waterhemp. Proc North Central Weed Sci Soc 65:59

Lorraine-Colwill DF, Powles SB, Hawkes TR, Hollinshead PH, Warner SAJ, Preston C (2003) Investigations into the mechanism of glyphosate resistance in Lolium rigidum. Pestic Biochem Physiol 74:62-72

Ma R, Kaundun SS, Tranel PJ, Riggins CW, McGinness DL, Hager AG, Hawkes T, McIndoes E, Riechers DE (2013) Distinct detoxification mechanisms confer resistance to mesotrione and atrazine in a population of waterhemp. Plant Physiol 163:363-377

Mohseni-Moghadam M, Schroeder K, Ashigh J (2013) Mechanism of resistance and inheritance in glyphosate resistant Palmer amaranth (Amaranthus palmeri) populations from New Mexico, USA. Weed Sci 61:517-523

Nandula VK, Ray JD, Ribeiro DN, Pand Z, Reddy KN (2013) Glyphosate resistance in tall waterhemp (Amaranthus tuberculatus) from Mississippi is due to both altered target-site and nontarget-site mechanisms. Weed Sci 61:374-383

Riggins C, Hager AG, Tranel P (2012) Three years of testing Illinois waterhemp populations for multiple resistance to glyphosate, PPO inhibitors, and ALS inhibitors. North Central Weed Sci Soc Proc 67:122

Rosenbaum KK, Bradley KW (2013) A survey of glyphosateresistant waterhemp (Amaranthus rudis) in Missouri soybean fields and prediction of glyphosate resistance in future waterhemp populations based on in-field observations and management practices. Weed Technol 27:656-663

Salas RA, Dayan FE, Pan Z, Watson SB, Dickson JW Scott RC Burgos NR (2012) EPSPS gene amplification in glyphosateresistant Italian Ryegrass (Lolium perenne ssp. Multiflorum) from Arkansas, USA. Pest Manag Sci 68:1223-1230

Schultz J, Riley EB, Wait JD, Bradley KW (2014) Distribution of multiple herbicide resistance in Missouri waterhemp populations. Weed Sci Soc Am Proc 54:290

Shaner DL, Lindenmeyer RB, Ostlie MH (2011) What have the mechanism of resistance to glyphosate taught us? Pest Manag Sci 68:3-9

Tamura K, Stecher G, Peterson D, Filipski A, Kumar S (2013) MEGA6: Molecular Evolutionary Genetics Analysis Version 6.0. Mol Biol Evol 30:2725-2729

Tranel PJ, Riggins CW, Bell MS, Hager AG (2011) Herbicide resistances in Amaranthus tuberculatus: a call for new options. J Agric Food Chem 59:5808-5812

VanGessel M (2001) Glyphosate-resistant horseweed from Delaware. Weed Sci 49: 703-705

Wakelin AM, Preston C (2006) A target-site mutation is present in a glyphosate-resistant Lolium rigidum population. Weed Res 46:432-440

Wiersma A (2012) Regional Whole Plant and Molecular Response of Kochia scoparia to Glyphosate. M.S. thesis. Fort Collins, CO: Colorado State University. 64 p

Received January 4, 2014, and approved September 30, 2014.

Chatham et al.: Glyphosate-resistant waterhemp • 55 